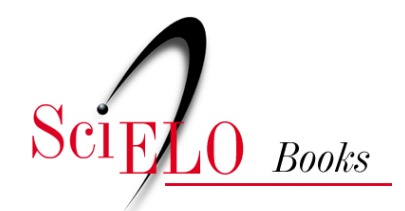

\title{
O relevo do estado do Rio de Janeiro cenário de beleza e fragilidade ambiental
}

\author{
Telma Mendes da Silva \\ Simone Lisboa dos Santos da Silva
}

\section{SciELO Books / SciELO Livros / SciELO Libros}

SILVA, T.M., and SILVA, S.L.S. O relevo do estado do Rio de Janeiro: cenário de beleza e fragilidade ambiental. In: MARAFON, G.J., and RIBEIRO, M.A. orgs. Revisitando o território fluminense, VI [online]. Rio de Janeiro: EDUERJ, 2017, pp. 43-64. ISBN: 978-85-7511-457-5. https://doi.org/10.7476/9788575114575.0004.

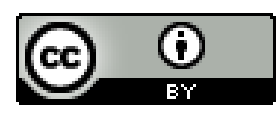

All the contents of this work, except where otherwise noted, is licensed under a Creative Commons Attribution 4.0 International license.

Todo o conteúdo deste trabalho, exceto quando houver ressalva, é publicado sob a licença Creative Commons Atribição $\underline{4.0}$.

Todo el contenido de esta obra, excepto donde se indique lo contrario, está bajo licencia de la licencia $\underline{\text { Creative Commons }}$ Reconocimento 4.0. 


\title{
0 relevo do estado do Rio de Janeiro: cenário de beleza e fragilidade ambiental
}

\author{
Telma Mendes da Silva ${ }^{1}$ \\ Simone Lisboa dos Santos da Silva ${ }^{2}$
}

\section{Introdução}

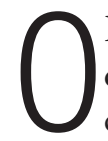
Rio de Janeiro é o menor estado da Região Sudeste do Brasil, com pouco mais de 43 milhões de $\mathrm{km}^{2}$, mas chama a atenção, tanto nacional como internacionalmente, por sua beleza cênica conferida pelos contrastes existentes entre as áreas elevadas e as planícies costeiras que contornam seu litoral, além de ilhas que enriquecem localmente a paisagem. No entanto, esse belo relevo contrastante também se mostra frágil no que concerne à atuação de processos erosivos e deposicionais que, paulatinamente, foram intensificados com o uso inadequado de seu solo e a ausência de uma política adequada de controle ambiental.

Está localizado no extremo leste do denominado Rift Continental do Sudeste do Brasil (RCSB) (Riccomini, 1989 e 1995), estendendo-se da região de serras e de depressões interplanálticas, que corresponde do vale do rio Paraíba do Sul à região dos maciços litorâneos, colinas e terrenos quaternários das baixadas de Guanabara, de Jacarepaguá, de Sepetiba, da Região dos Lagos e da planície costeira de Campos. Caracteriza-se pelo contraste significativo das formas de relevo, resultante da complexa evolução geológico-geomorfológica mesozoico-cenozoica do Sudeste brasileiro e, ainda, do processo acentuado de alteração da paisagem resultante das condições do regime climático tropical úmido.

Dentro da complexa história de evolução geológica, corresponde ao Mesozoico (230 Ma [milhões de anos] a $65 \mathrm{Ma}$ ), o início de um período de instabilidade tectônica (evento sul-atlantiano ou reativação wealdeniana), relacionado ao mecanismo de separação das placas tectônicas sul-americana e africana, e consequente formação do Oceano Atlântico, gerando um episódio de rifteamento seguido de contração termal. $\mathrm{Na}$ fase rift, tem-se a origem das serras do SE e das bacias da margem continental brasileira, onde se inserem os terrenos elevados (serras da Mantiqueira e do Mar) e as

\footnotetext{
1 Universidade Federal do Rio de Janeiro.

${ }^{2}$ Universidade do Estado do Rio de Janeiro.
} 
depressões tectônicas do SE brasileiro (vale do rio Paraíba do Sul, Baía de Guanabara, entre outras) (Asmus e Ferrari, 1978; Riccomoni, 1989; Macedo et al., 1991).

No que se refere à litologia, o território fluminense caracteriza-se por apresentar áreas de sedimentos terciários e quaternários, além de áreas de rochas ígneas e metamórficas pré-cambrianas. As primeiras podem ser observadas de modo mais expressivo na bacia de Resende e no litoral, onde se encontram o Grupo Barreiras, a Formação Macacu e as planícies aluvionares e marinhas. Já as áreas pré-cambrianas, submetidas a intensas deformações, em função de eventos tectônicos, e à ação de fatores climáticos atuais e passados, mostram-se distribuídas. Essas diferentes unidades litológicas foram retrabalhadas em condições de regime tipicamente tropical, caracterizado, em linhas gerais, por altas temperaturas e elevados índices pluviométricos, o que representa elevadas taxas nos processos pedo-geomorfológicos de alteração da paisagem.

A orografia determina uma série de variedades climáticas, tanto no que se refere à temperatura quanto à precipitação. Por sua posição geográfica próxima ao litoral e pelos meses de verão de intensa radiação solar recebida, têm-se, nessa região, elevados índices de umidade do ar e de temperatura, o que leva à ocorrência de chuvas frequentes de distribuição diferenciada, devido, ainda, à existência de inúmeras elevações altimétricas ao longo de sua costa (serra do Mar e maciços costeiros), que contribuem para eventos pluviométricos de elevada magnitude. As chuvas são ainda comuns nos episódios de entradas de frente fria de origem polar, que, ao encontrarem as altas temperaturas e a umidade, resultam em eventos pluviométricos de dimensões consideráveis, gerando à população desagradáveis transtornos com a ocorrência de movimentos gravitacionais de massa e enchentes.

$\mathrm{Na}$ região litorânea e nas serras adjacentes, há um comportamento semelhante com pequenas variações, de acordo com o posicionamento geográfico: municípios localizados nas baixadas costeiras, no sopé ou na baixa encosta da serra do Mar e no reverso da serra do Mar. As amplitudes médias de variação térmica parecem ser ligeiramente maiores somente nas estações que se situam no reverso da serra do Mar, ou seja, mais interioranas, permanecendo com valores bem próximos para áreas localizadas nas baixadas e sopés de elevações (variando acima de $22^{\circ} \mathrm{C}$, nos meses de verão, a aproximadamente $20^{\circ} \mathrm{C}$ nos meses de inverno). Apenas nas áreas que se encontram em altitudes relativamente elevadas (Petrópolis, Teresópolis e Nova Friburgo) é que se observa uma queda geral dos valores das normais térmicas $\left(20^{\circ} \mathrm{C}\right.$ nos meses de verão e cerca de $15^{\circ} \mathrm{C}$ no inverno).

Em relação à distribuição pluviométrica anual, há também uma estação seca bem delineada nos meses de inverno. A baixada caracteriza-se por precipitações médias anuais inferiores a $1.500 \mathrm{~mm}$. No entanto, os municípios localizados no topo da serra do Mar, como Teresópolis e Nova Friburgo, são os que apresentam totais de precipitação bem mais elevados durante os meses de verão e os totais anuais mais elevados: valores médios superiores a $2.000 \mathrm{~mm} / \mathrm{ano}$. Ressalta-se, ainda, que os índices pluviométricos mais elevados, tanto no verão quanto no inverno, recaem sobre as localidades do sopé ou encosta inferior da serra do Mar, ultrapassando $60 \mathrm{~mm}$ mensais nos meses de inverno.

Após esta breve contextualização do estado, neste capítulo procuramos discutir os principais fatos históricos que envolveram a formação e a evolução das formas de relevo, assim como aqueles ligados à ocupação de seus terrenos e que, de uma forma ou de outra, facilitam (ou facilitaram) ou apresentam (ou apresentaram) restrições em função dos recursos naturais existentes e que, por outro lado, podem estar associados a problemas ambientais - alguns deles prolongados ou implicados com questões ainda presentes na atualidade. 


\section{Origem dos contrastes das feições de relevo no estado do Rio de Janeiro}

O estado do Rio de Janeiro, portanto, caracteriza-se pela presença de extensas planícies flúvio-marinhas, também conhecidas como baixadas, que bordejam a costa e se situam pouco acima do nível do mar, apresentando-se, em grande parte, embrejadas e entremeadas por lagoas, além da ocorrência de feições arredondadas e convexas correspondentes a colinas suaves isoladas e morros, que chegam a atingir $200 \mathrm{~m}$ de altitude (Figura 1). À medida que nos aproximamos dos contrafortes da serra do Mar, esses morros se tornam cada vez mais numerosos, com vales mais estreitos entre eles, o que demonstra o intenso processo de dissecação da escarpa serrana (Figura 2).

Figura 1. Mapa das feições de relevo do Rio de Janeiro. 1 - Paraty; 2 - Angra dos Reis; 3 - Itatiaia; 4 - Barra Mansa; 5 - Volta Redonda; 6 - Nova Iguaçu; 7 - Niterói; 8 - Maricá; 9 - Itaboraí; 10 - Araruama; 11 - Três Rios; 12 - Petrópolis; 13 - Cachoeiras de Macacu; 14 - Miracema; 15 - Campos de Goytacazes; 16 - Santa Maria Madalena; 17 - Conceição de Macabu; 18 - Macaé; 19 - Rio de Janeiro.

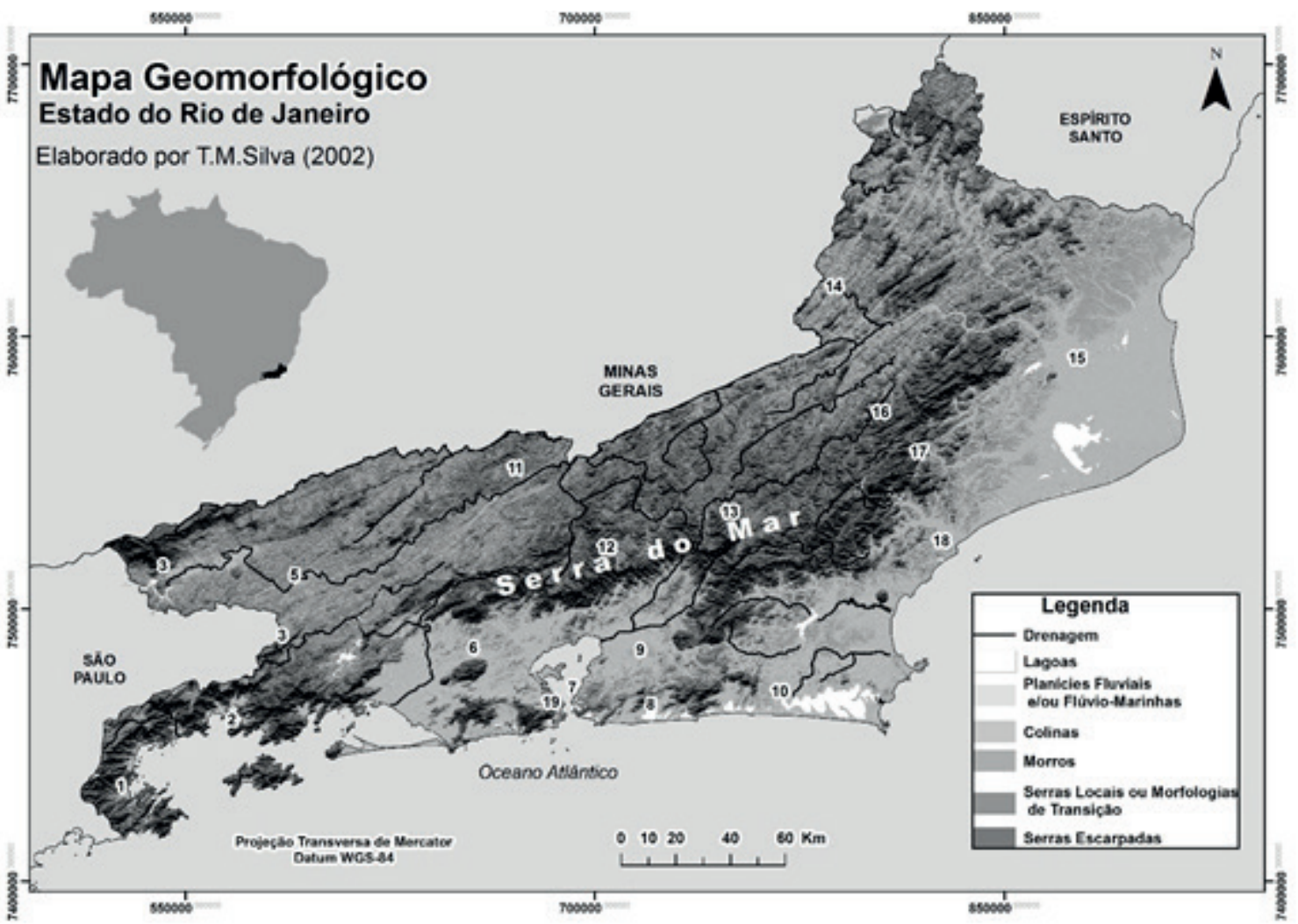

Fonte: Modificado de Silva (2002). 
Figura 2. Imagem demonstrando as feiçōes morfológicas típicas do entorno do estado do Rio de Janeiro: em primeiro plano, as planícies flúvio-marinhas da bacia do rio Guapi-Macacu e as feições de colinas e morros que vão se intensificando à medida que se aproximam da serra do Mar.

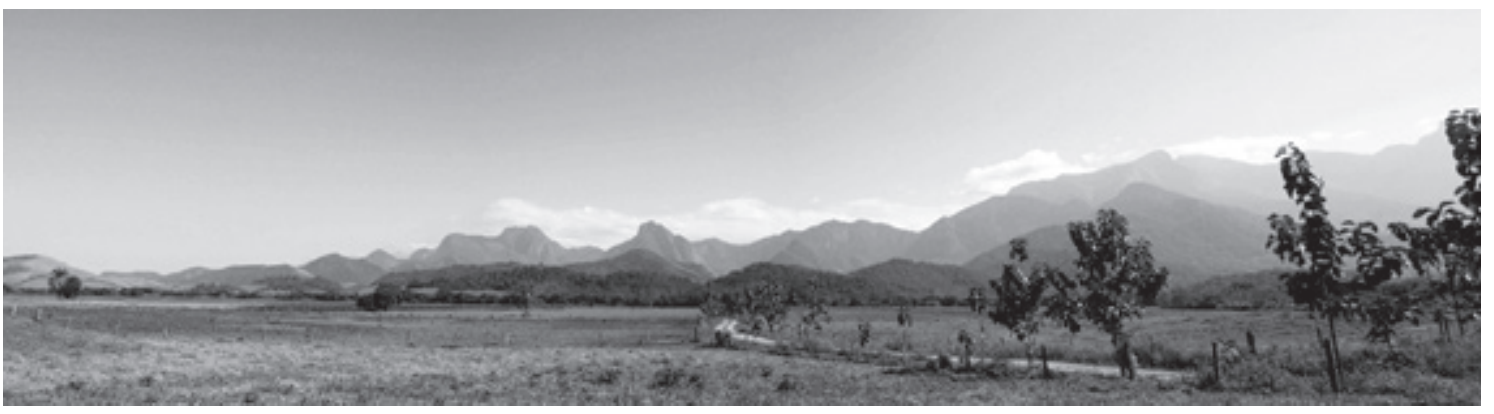

Foto: T. M. Silva (agosto de 2010).

Ainda ao longo da costa, encontram-se os maciços costeiros, correspondentes a elevações isoladas e paralelas, com altitudes entre 500 e 1.000 m. No segmento a leste da Baía de Guanabara, estão as serras da Tiririca, com elevações entre 200 e 410 m, e do Sambé, com altitude máxima de 610 m; no segmento a oeste, encontram-se os maciços de dimensões e formas mais imponentes conhecidos como Gericinó-Mendanha (974 m), Pedra Branca (1.024 m) e Tijuca (1.021 m), estes últimos mais próximos à costa (Figura 3).

Figura 3. Mapa com maciços costeiros e baixadas nos arredores da Baía de Guanabara. Maciços Costeiros: 1) Tijuca; 2) Pedra Branca; 3) Suruí; 4) Região dos Lagos. Maciços Alcalinos: 5) Mendanha; 6) Tinguá; 7) Itaúna; 8) Tanguá-Rio Bonito. A) Forte de São João; B) Forte de Santa Cruz.

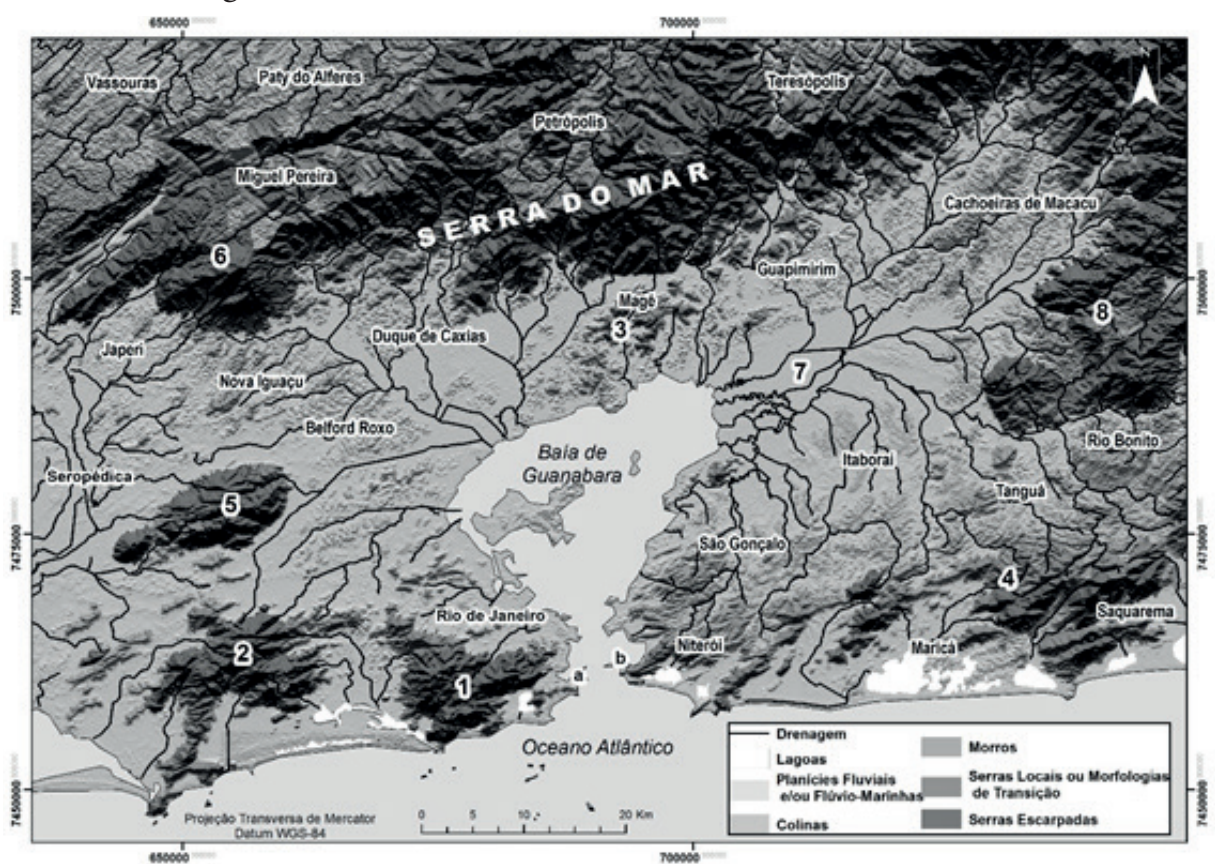

Fonte: Modificado de Silva (2002). 


\section{0 relevo do estado do Rio de Janeiro: cenário de beleza e fragilidade ambiental}

Alguns morros menores isolados são encontrados na região metropolitana do Rio de Janeiro e representam um grande atrativo para a atividade turística, como os morros do Leme, Urubus, Babilônia, Cara de Cão, Viúva, Outeiro da Glória, Pão de Açúcar, entre outros, que moldam o relevo no entorno das águas da Baía de Guanabara e tanto contribuem para a beleza cênica da cidade. Muitos desses morros mergulham diretamente no mar, formando costões abruptos interrompidos por fraturas e diáclases, que são continuamente retrabalhadas pela ação das ondas e fornecem um aspecto ímpar à cidade, conhecida como maravilhosa, devido ao cenário geomorfológico esculpido por milhares de anos (Fernandes et al., 2010).

Figura 4. Fotografia panorâmica que destaca a Baía de Guanabara e as feições de morros e maciços no entorno.

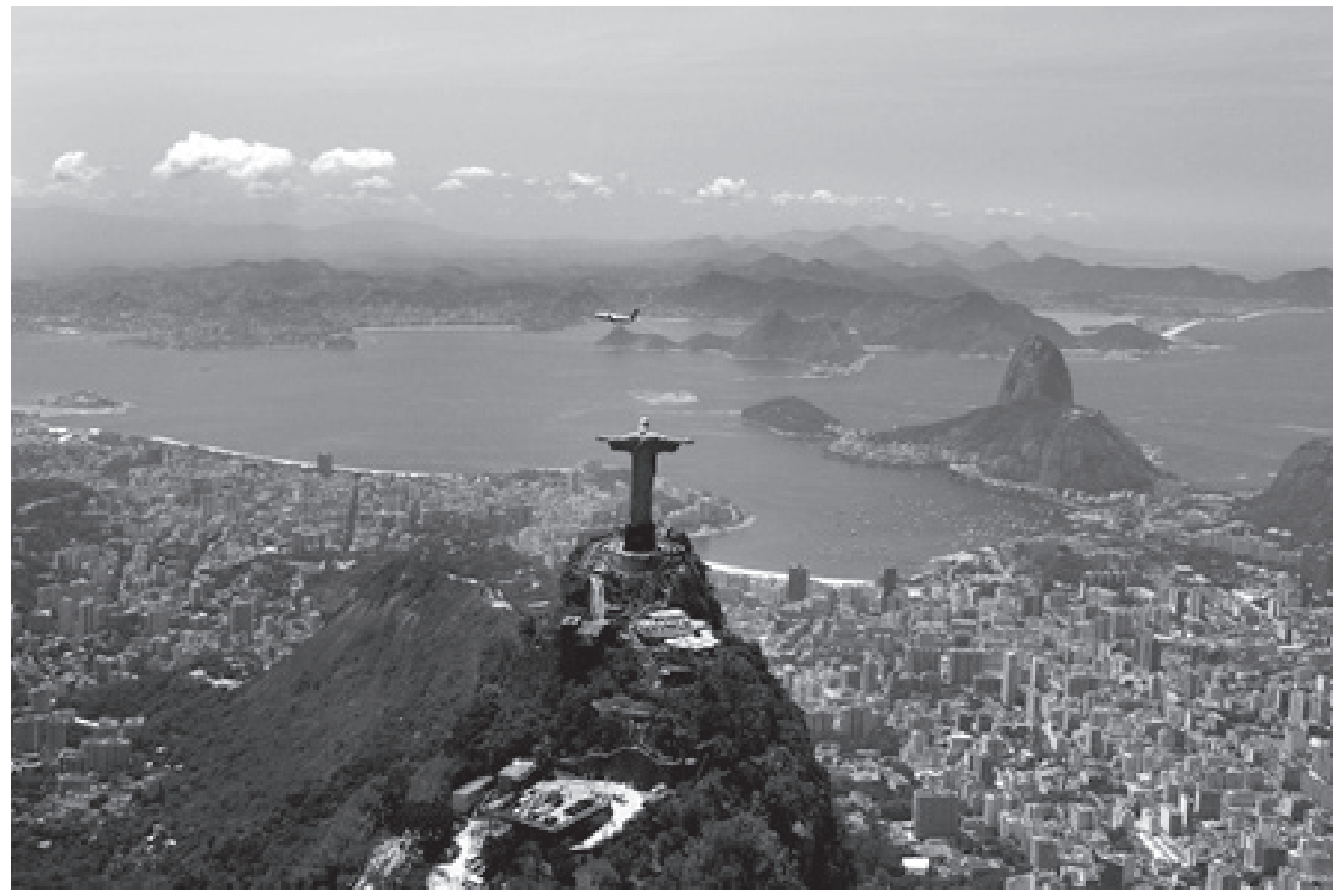

Foto: T. M. Silva (outubro de 2006).

A majestosa feição da serra do Mar, que isola a baixada flúvio-marinha do planalto interior (Figura 1), atinge altitude de $2.316 \mathrm{~m}$, e tem como seu ponto culminante o Pico Maior dos Três Picos, localizado na divisa dos municípios de Teresópolis e Nova Friburgo. Essa escarpa serrana é cortada por uma notável rede de drenagem, que desce torrencialmente pelas encostas rochosas, onde se formam corredeiras e cachoeiras cercadas por uma mata densa e exuberante e que tanto encantam os visitantes.

Essas características gerais do relevo fluminense são fruto de uma história geológica peculiar, pois, apesar de sabermos que nas áreas de choque entre as placas tectônicas é que encontramos as gran- 
des cadeias de montanhas, como a Cadeia Andina, a Cadeia do Himalaia, entre outras, a ocorrência da serra do Mar e dos maciços litorâneos no estado do Rio de Janeiro (fora de uma área previsível para formação montanhosa) provoca a curiosidade de pesquisadores e visitantes, principalmente entre os geólogos (Ferrari, 2012). Além disso, as formas do estado do Rio de Janeiro correspondem a um relevo relativamente jovem, modelado em um terreno geológico muito antigo, ou seja, as rochas que sustentam esse relevo são quase quinhentos milhões de anos (Ma) mais antigas do que as formas de relevo impressas na paisagem, demonstrando que há episódios geológicos distintos que explicam essa morfologia.

A Figura 5 se refere a um mapa simplificado dos dois domínios geológicos que predominam no estado do Rio de Janeiro: o das rochas cristalinas, que cobrem cerca de $80 \%$ de seu território, e o dos sedimentos que preenchem as áreas deprimidas das bacias de drenagem e/ou sedimentos litorâneos distribuídos ao longo de toda a costa. As rochas cristalinas são, predominantemente, compostas por gnaisses e granitos gerados entre 790 a $480 \mathrm{Ma}$, em processos colisionais das placas litosféricas durante a formação do supercontinente Gondwana, de idade entre o Neoproterozoico e o Paleozoico Inferior (Heilbron et al., 2008; Tupinambá et al., 2012).

Figura 5. Os grandes domínios geológicos do estado do Rio de Janeiro: o domínio de rochas cristalinas corresponde aos terrenos pré-cambrianos, enquanto o domínio dos sedimentos é representado pelos terrenos terciários e quaternários.

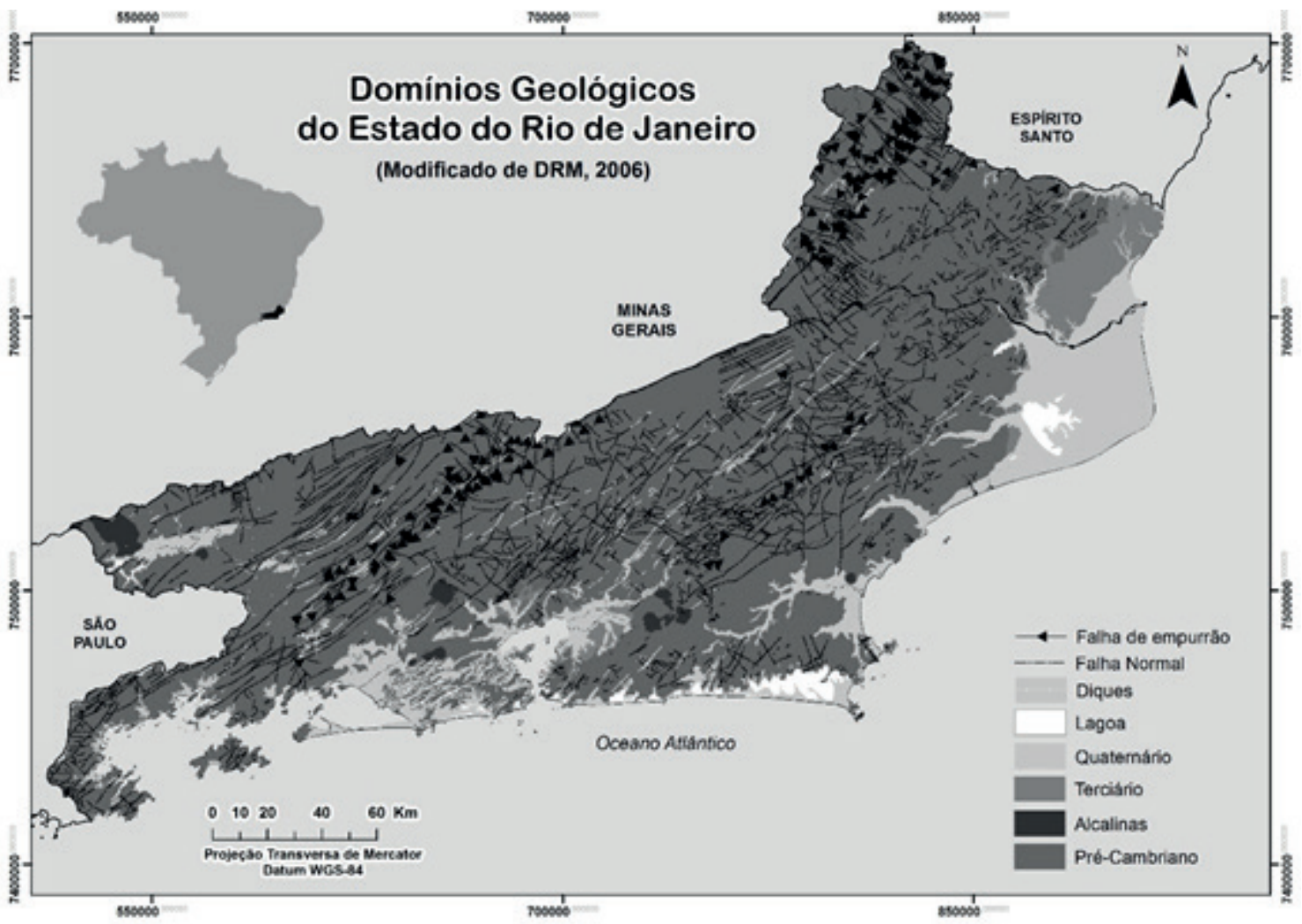

Fonte: Modificado de DRM, 2006. 


\section{0 relevo do estado do Rio de Janeiro: cenário de beleza e fragilidade ambiental}

Outro episódio geológico importante diz respeito à intrusão no embasamento cristalino por um enxame de diques básicos que precederam a quebra do Gondwana e a abertura do Oceano Atlântico Sul durante o Cretáceo Inferior (127 a 130 Ma). No Paleógeno, por sua vez, um regime distensivo desenvolveu importante falhamento em blocos, os quais, associados ao magmatismo alcalino, de idade entre 70 e $50 \mathrm{Ma}$ e caráter raso, estão registrados nos corpos subvulcânicos e intrusivos que se destacam na paisagem, como os maciços do Mendanha, Tinguá, Itaúna e Tanguá-Rio Bonito. Esse regime distensivo também deu origem à feição tectono-estrutural do Gráben da Guanabara, que pode ser identificada pela orientação ENE-WSW da baía, e aos depósitos cenozoicos, que correspondem às feições de planícies flúvio-marinhas mapeadas na Figura 1.

Asmus e Ferrari (1978) interpretam a estruturação do relevo na região que compreende uma estreita faixa, de 50 a $100 \mathrm{~km}$ de largura e com cerca de $1.000 \mathrm{~km}$ de comprimento, entre a cidade de Florianópolis (SC) e o médio vale do rio Paraíba do Sul, como resultado de falhamentos normais, com até $3.000 \mathrm{~m}$ de rejeito vertical, ao longo de linhas de fraqueza pré-cambrianas, as quais, entre o Paleoceno e o Plioceno, deram lugar ao deslizamento gravitacional de blocos, atualmente expressos por escarpas de linha de falha (serra do Mar, serra da Mantiqueira e maciço Carioca) e, entre estas, por semigrábens (vale do rio Paraíba do Sul e Baixada Fluminense) (Figura 6).

Figura 6. Perfil geológico esquemático, sem escala, transversal à área afetada pelo tectonismo cenozoico, ressaltando o caráter escalonado dos falhamentos e o basculamento dos blocos de relevo resultantes da serra da Mantiqueira aos maciços litorâneos (A - A').

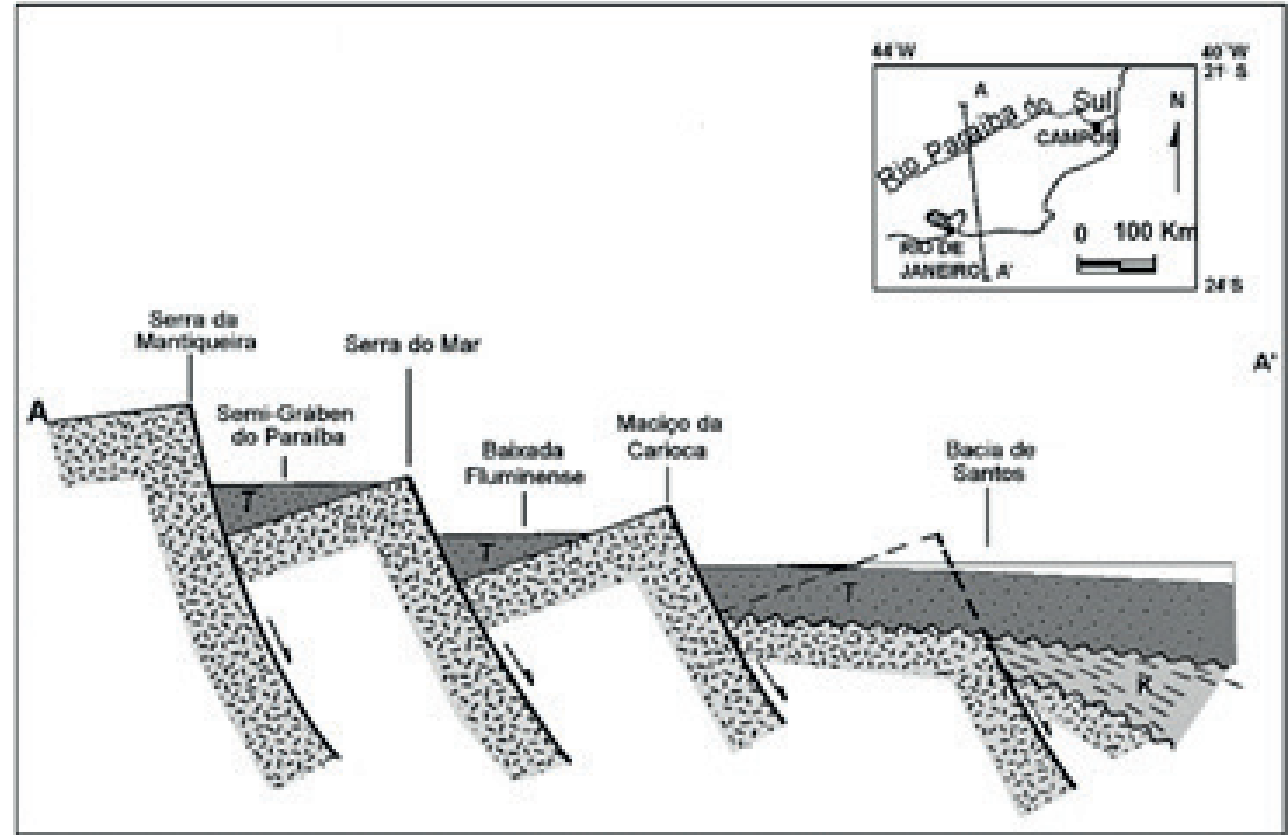

Fonte: Asmus e Ferrari (1978). K - sedimentos cretáceos, T - sedimentos terciários. 
Macedo et al. (1991) assinalam que a Região Sudeste foi - e talvez ainda seja - palco de intensa atividade tectônica durante o cenozoico. A disposição de falhas reativadas profundas, bacias, montanhas, vulcanismo e sismos recentes sugere um complexo de falhas normais/transcorrentes, seguindo subparalelamente à linha de costa do estado do Rio de Janeiro. Todos os autores consultados concordam que o tectonismo cenozoico no Sudeste do Brasil, embora residual, foi e continua a ser fundamental para o entendimento da evolução da paisagem no que diz respeito às mudanças na topografia e nos sistemas de drenagem, divergindo apenas quanto à intensidade dessas mudanças.

Os contrastes litológicos presentes condicionam uma intensa erosão diferencial, com as escarpas mais expressivas sendo suportadas por rochas granitoides, gnáissicas e quartzíticas. Os exemplos mais notáveis seriam as escarpas da Mantiqueira, dos Órgãos e da Bocaina; as intrusões alcalinas também são responsáveis por acentuados desníveis, como os de Itatiaia, Passa Quatro, Tinguá e Rio Bonito.

Nesse contexto, tanto o meio geológico quanto o geomorfológico estão associados a fontes de riquezas minerais, das águas, dos solos férteis, dando origem também a relevos de altitudes distintas e vales. Representam, assim, a base da cultura humana, atuando como suporte físico (substrato) para o desenvolvimento e fornecendo material para sua subsistência (Schmitt et al., 2004). Dessa forma, no próximo tópico, exemplificamos de que forma essas características físico-ambientais do Rio de Janeiro permearam a formação e a organização das atividades socioeconômicas desenvolvidas.

\section{Os condicionantes do relevo e o histórico de uso e ocupação do Rio de Janeiro}

O reconhecimento das características do relevo permite identificar os fatores favoráveis ou desfavoráveis à ocupação, as limitações e as possibilidades de uso dos solos, bem como a suscetibilidade potencial à erosão, revelando-se, portanto, essencial para a definição das áreas de preservação e de indicação de uso restrito e de ocupação urbana e/ou agrícola (Silva, 2009). Dessa forma, a paisagem do estado do Rio de Janeiro não pode ser considerada estática, representando personagem ativa e testemunhal de acontecimentos e intervenções ocorridos ao longo dos séculos de ocupação (Pinheiro, 2005).

No breve histórico acerca da ocupação e do uso dos recursos naturais do estado do Rio de Janeiro, debatemos a importância das características geológico-morfológicas em seu desenvolvimento, bem como nos entraves resultantes do uso inadequado dos recursos existentes.

Quando as naus comandadas por Américo Vespúcio cruzaram a barra do Rio de Janeiro, em $1^{\text {o. }}$ de janeiro de 1502 , desvendaram ao mundo um dos mais belos cenários da face da Terra, a Baía de Guanabara, envolto por pontais, enseadas, praias e uma exuberante mata tropical (Amador, 2012). No entanto, essa área já apresentava vestígios mais remotos da ocupação humana. A partir da investigação sobre os sambaquis, foram encontrados, ao longo da faixa litorânea, em pontos estratégicos do antigo estuário, bem como nas proximidades das lagunas, canais fluviais, manguezais, restingas e florestas, locais em que havia disponibilidade de água potável. Essa forma de ocupação está associada a uma fase de modificações ambientais com crescimento expressivo dos recursos marinhos, chamada de "ótimo climático", ocorrido entre 6.000 e 5.000 anos A.P. (Antes do Presente), quando se registrou 


\section{0 relevo do estado do Rio de Janeiro: cenário de beleza e fragilidade ambiental}

a elevação da temperatura e do nível do mar. Por sua vez, por volta de 3.000 anos A.P., a diminuição dos recursos marinhos típicos da formação dos sambaquis foi compensada na dieta alimentar pela coleta de vegetais, caça a pequenos animais e pesca (Amador, 1992).

Esses assentamentos litorâneos datados até cerca de 1.000 anos A.P. representam importantes marcadores das variações do nível do mar em tempos pretéritos, pois alguns sambaquis foram encontrados até cerca de $5 \mathrm{~km}$ da linha de costa da baía da Guanabara, atribuindo-se a mudança da localização a eventos de transgressão marinha, em que faixas ecológicas foram empurradas terra adentro e os afloramentos rochosos tornaram-se ilhas, com a ocupação humana refugiando-se nesses pontos topograficamente mais elevados. Durante os eventos de regressão marinha quaternária, os indígenas reocuparam antigos habitats, recolonizando mangues secos ou dunas fixas (Prous, 1992). Assim, fazendo nossas as palavras de Serra e Serra (2012), é possível considerar que essa população pré-histórica manteve relação de uso bastante harmônica com os terrenos e os recursos naturais existentes.

Já com o início da ocupação portuguesa, em 1565, houve as primeiras intervenções locais, com a criação de um núcleo urbano que buscou favorecer a definição dos direitos de propriedade da terra e dos recursos naturais encontrados, bem como garantir a segurança da colônia em relação a possíveis invasores. A escolha pelo Rio de Janeiro vinculou-se à importância da conformação de seu sítio para a proteção de ataques inimigos e à possibilidade de estabelecer fortificações em locais como a entrada da baía e ao longo dos rios.

Durante o período colonial, morros e costôes rochosos ofereceram, portanto, um frente bastante eficiente de defesa natural para esquadras que se abrigavam das tempestades, funcionando também como proteção para eventuais inimigos no interior da baía (Pinheiro, 2005). Algumas dessas fortificações ainda podem ser encontradas nos arredores da Baía de Guanabara, como as apresentadas na Figura 7.

Figura 7. A. Forte da Laje e parte do Forte de São João ao fundo, localizado no bairro da Urca; B. Detalhe do forte da Laje.

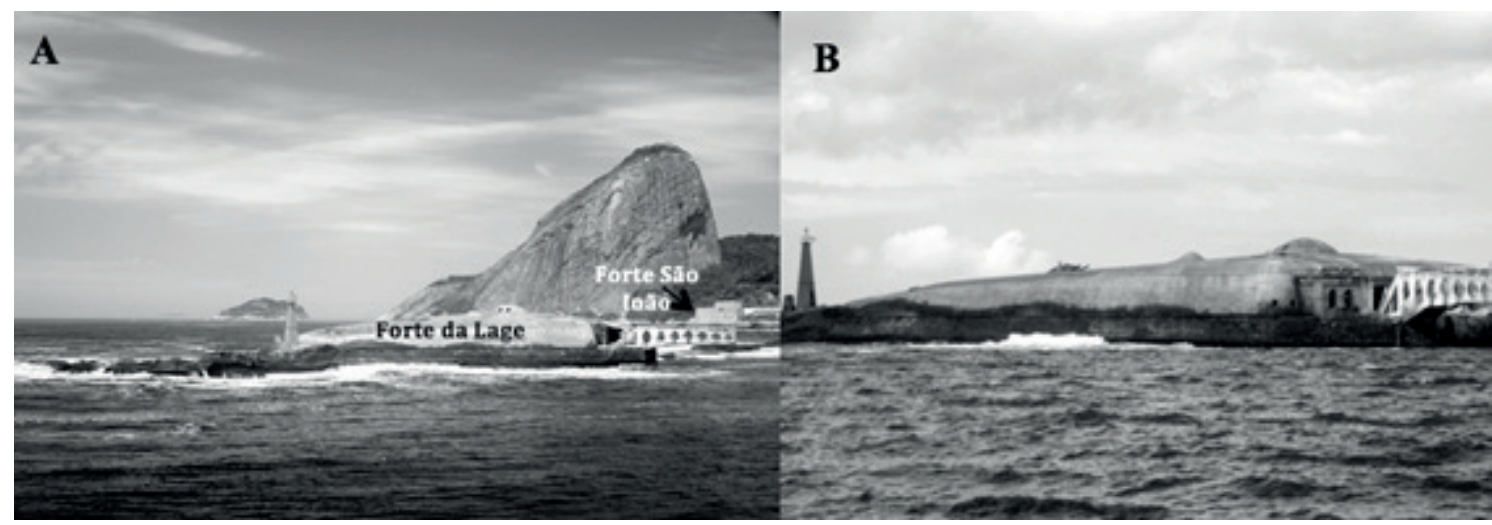

Fotos: T. M. Silva, jun. 2010. 
Nos anos seguintes, houve intervenção direta dos portugueses sobre a cobertura florestal do Rio, com a extração praticamente total da Mata Atlântica, em função do escambo de pau-brasil com os indígenas. Essa atividade extrativa se prolongou até o século XIX, destruindo vastas extensões florestais e, dessa forma, levando à erosão dos solos e à perda de mananciais de água, principalmente aquelas existentes nos maciços litorâneos que abasteciam a população na época colonial.

O século XVII foi marcado pelas experiências agrícolas vinculadas à produção de cana-de-açúcar e a seus engenhos, que marcaram principalmente a região do Norte fluminense, onde foram aproveitados os terrenos suaves (que caracterizam o topo das feiçôes de tabuleiros costeiros desenvolvidos em sedimentos da Idade Terciária - Formação Barreiras), local com um regime climático de estações bem demarcadas. Esses aspectos físico-ambientais são os mais adequados a esse cultivo extremamente rigoroso, que demanda terrenos planos ou ligeiramente inclinados, solos férteis e não sujeitos a encharcamentos, e que apresente um período seco que esteja diretamente relacionado à maturação ideal do cultivo. Nessa área do estado, é possível ainda encontrar representantes das fazendas dos antigos barôes do açúcar e de algumas usinas. Já na área metropolitana do Rio de Janeiro, a cana-de-açúcar também foi introduzida nas áreas das baixadas de Sepetiba (por exemplo, bairro de Santa Cruz) e da Baía de Guanabara (por exemplo, bairro de Bangu), onde houve grandes transformações nesse período. No entanto, atualmente, poucos são os vestígios encontrados nesses terrenos que correspondem à área urbanizada do extremo oeste da RMRJ.

No século XVII, também houve penetração agropastoril, que exigia vastas extensões de terra e levou ao desmatamento e às queimadas das áreas de baixadas pela mão de obra escrava de negros ou indígenas, gerando, consequentemente, acentuada perda da biodiversidade local, além de haver redução do número e do volume dos cursos fluviais, erosão e perda de fertilidade dos solos, bem como assoreamento das lâminas d'água (rios, lagoas e brejos) (Serra e Serra, 2012). Mas, com a descoberta das reservas auríferas das Minas Gerais, houve uma reorganização do povoamento fluminense, e a exploração de ouro influenciou, de forma indireta, a ocupação do território. O escoamento da produção, que descia do planalto das Minas Gerais (em lombos de burros), rumava até Paraty, pelo então denominado "Caminho Velho", e daí pelo mar até o porto do Rio de Janeiro. Desse período em diante, o Rio de Janeiro tornou-se o principal porto e a cidade mais ativa do país.

A atividade aurífera contribuiu para o surgimento de vilas que serviam de passagem pelo interior, em localidades nas quais os vales fluviais se abriam, com a formação de alvéolos que permitiam a ocupação, como ocorreu com a fundação e o crescimento dos municípios de Vassouras, Paraíba do Sul e Paty do Alferes, entre outros. Toda essa gama de atividades levou a Coroa a valorizar os terrenos do estado do Rio de Janeiro, o que culminou com a transferência da sede do governo colonial de Salvador para o Rio de Janeiro em 1763. Isso a transformou na cidade mais importante da colônia, e seu porto, no mais dinâmico de todos os existentes no litoral. Assim, a área correspondente ao que hoje se chama Região Metropolitana do Rio de Janeiro (RMRJ) desempenhou papel de destaque, por ser a sede da capital do Brasil entre 1763 a 1960, sendo a mais populosa do país por quase todo esse período (Abreu, 2006).

No entanto, em fins do século XVIII, com a redução da produção aurífera, boa parte da população que vivia na cidade se viu praticamente obrigada a buscar alternativas para sua sobrevivência, sendo a atividade agropastoril reafirmada como aquela que oferecia melhores e maiores condições para o desenvolvimento do Rio de Janeiro. Mas, à medida que o Império se consolidava, surgia um novo produto-rei na economia fluminense: o café. Essa nova cultura de base exportadora iniciou seu trajeto 


\section{0 relevo do estado do Rio de Janeiro: cenário de beleza e fragilidade ambiental}

na cidade do Rio de Janeiro, mais precisamente no maciço Carioca, nas encostas íngremes das vertentes voltadas para Jacarepaguá, além de ser introduzida nos maciços da Pedra Branca e do Gericinó-Mendanha. Nas encostas íngremes do maciço da Tijuca, esse cultivo acabou por quase destruir os mananciais hídricos que abasteciam a cidade, razão pela qual o governo imperial desapropriou sítios e fazendas para reflorestar a região. Essa área corresponde, na atualidade, à maior floresta urbana do mundo, o Parque Nacional da Tijuca.

Desse modo, com a restrição de plantio na capital federal, o café se expandiu para os terrenos do planalto, em diferentes municípios do território fluminense. Nesse período, houve uma das maiores expressões cafeeiras da antiga província, com o café atingindo "São João Marcos" (parte do atual município de Rio Claro), Piraí e Resende, até alcançar o vale do Paraíba, em seu trecho médio. Assim, no Médio Paraíba fluminense, o café teve seu plantio expandido em várias direções e foi cultivado desde o norte, em Entre Rios (atual município de Três Rios), seguindo por Nova Friburgo e Cantagalo, na Região Serrana, até Itaocara e São Fidélis.

No entanto, no estado do Rio de Janeiro, a produtividade do café não obteve o resultado esperado, mais uma vez devido à elevada declividade dos terrenos e dos solos, mineralogicamente pobres, levando a intensos processos de erosão e perda do solo. Além disso, também o regime climático impróprio foi decisido, pois, dependendo da espécie de cultivo, o café só se desenvolve bem em áreas que apresentem uma média de temperatura entre $18^{\circ} \mathrm{C}$ e $24^{\circ} \mathrm{C}$. Temperaturas muito baixas, mesmo que por poucos dias por ano, não são aceitáveis. E o regime de chuvas ideal é aquele com chuvas bem distribuídas durante todo o ano e com uma precipitação total entre $600 \mathrm{~mm}$ e $1.500 \mathrm{~mm} /$ ano - características que não são encontradas no território fluminense. No entanto, mesmo com todos esses empecilhos naturais, as áreas de cafezais viveram um período áureo de produtividade e grande riqueza, com imponentes sedes das fazendas e instalaçóes de beneficiamento do produto ocupando os segmentos dos fundos dos vales. Muitas dessas instalaçóes, principalmente aquelas do Médio Paraíba, foram resgatadas pela atividade turística nas últimas décadas, procurando-se manter vivo esse período econômico áureo do estado.

Ressalta-se ainda que esse sítio, como, por exemplo, o da RMRJ, que tanto favoreceu a instalação de fortalezas que protegiam o território brasileiro, viria a ser um grande balizador para o desenvolvimento urbano da cidade. Segundo Abreu (2006), essa mesma característica que confere à cidade uma paisagem bela e única também causou diversos problemas, não somente pela falta de espaço, mas também pela ocupação deáreas impróprias, como encostas de morros efundos de vale alagadiços, gerando a constante necessidade de gerenciamento para não desencadear eventuais processos de degradação ambiental.

Dessa forma, houve necessidade de aterrar extensas áreas nesse trecho do estado, levando-se em conta a inexistência de terrenos para a expansão do sítio urbano. A abertura de espaços revelou-se de primordial importância para o desenvolvimento da cidade, efetuando-se, assim, várias modificações na paisagem natural, ou seja, alterações diretas sobre o relevo da cidade, como, por exemplo, o desmonte de morros e o aterro de diversas áreas, com vistas ao crescimento urbano.

As modificações urbanas ocorridas na cidade do Rio de Janeiro tiveram, em sua maior parte, origem nas reformas urbanas. Um dos melhores exemplos foi o desmonte do morro do Castelo, que teve grande significado histórico, pois foi a área escolhida pelos portugueses, logo após a expulsão definitiva dos franceses, que dominavam a Guanabara, para a construção das primeiras casas e fortificaçôes definitivas da cidade (Figura 7). No entanto, com o passar do tempo, os bairros do Castelo e 
da Misericórdia, situados na área do morro, tornaram-se sinônimo de insalubridade e doença, e esses foram os principais motivos de sua destruição.

Tal modificação da paisagem urbana pode ser vista ainda como uma das mais significativas, decorrente dos ideais sanitaristas que alteraram a feição urbana da cidade desde a reforma Pereira Passos, embora tenha ocorrido de fato durante a reforma Carlos Sampaio. Isso porque as reformas empreendidas pela administração do prefeito Carlos Sampaio no Rio de Janeiro (1920-1922) estavam ligadas não somente à sanitarização da cidade, mas também à tentativa de embelezá-la para os festejos de comemoração dos cem anos de independência do Brasil (Abreu, 2006).

Figura 8. Morro do Castelo ainda com sua ocupação original, em 1914.

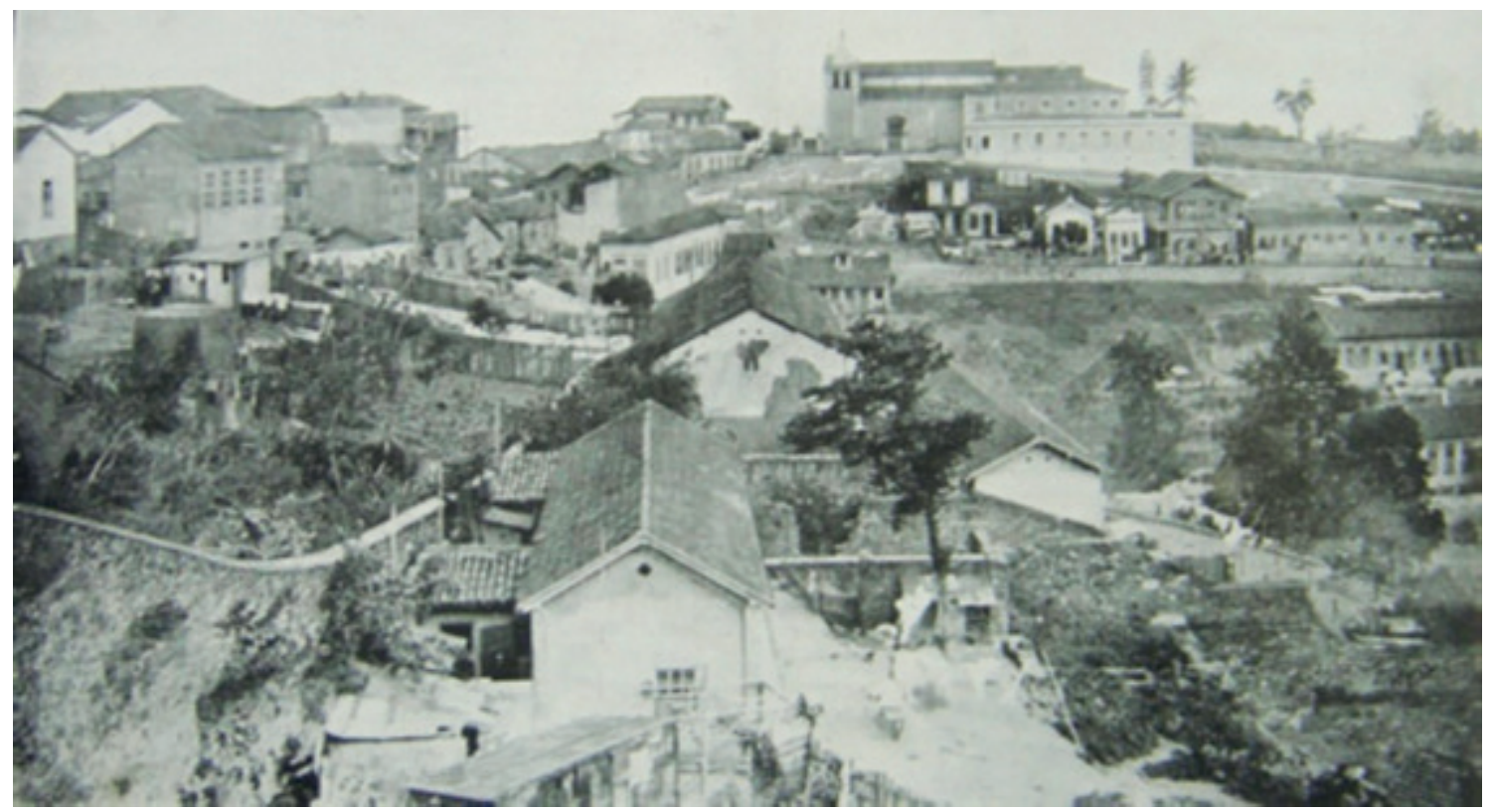

Fonte: http://zrak7.ifrance.com/castello-morro.jpg.

Assim, com o desmonte do Morro do Castelo, pretendia-se dar uma nova funcionalidade à sua área central, que, nesse período, já apresentava significativa importância na política e na economia nacional, de modo que representasse a paisagem-símbolo de uma nação emergente e contemporânea. Em novembro de 1920, então, teve início o desmonte do morro do Castelo, e parte do rejeito foi aproveitada para o aterro da Praça Mauá, do Cais do Porto e da avenida Rodrigues Alves. Além disso, nesse mesmo período, a cidade ainda era a capital do Brasil e, para um país que queria mostrar ao mundo seu crescimento econômico, uma paisagem caracterizada como um centro velho e insalubre não era desejável; ao contrário, requeria-se a abertura de áreas para a instalação de largas avenidas e prédios mais novos, sendo, portanto, necessária a mudança na conformação da paisagem do centro da cidade.

Desse modo, com o desmonte do morro (Figuras 9A e 9B), tornou-se possível a construção da avenida Presidente Antônio Carlos (Figura 9C), evento necessário ao desenvolvimento do transporte 
urbano na cidade, e, com o material do desmonte, foi possível ainda aterrar outras áreas da cidade, inclusive partes da Lagoa Rodrigo de Freitas.

Figuras 9A e 9B. Desmonte do morro do Castelo, iniciado em 1921. Figura 9C. Avenida Presidente Antônio Carlos e urbanização da Esplanada do Castelo em 1944.

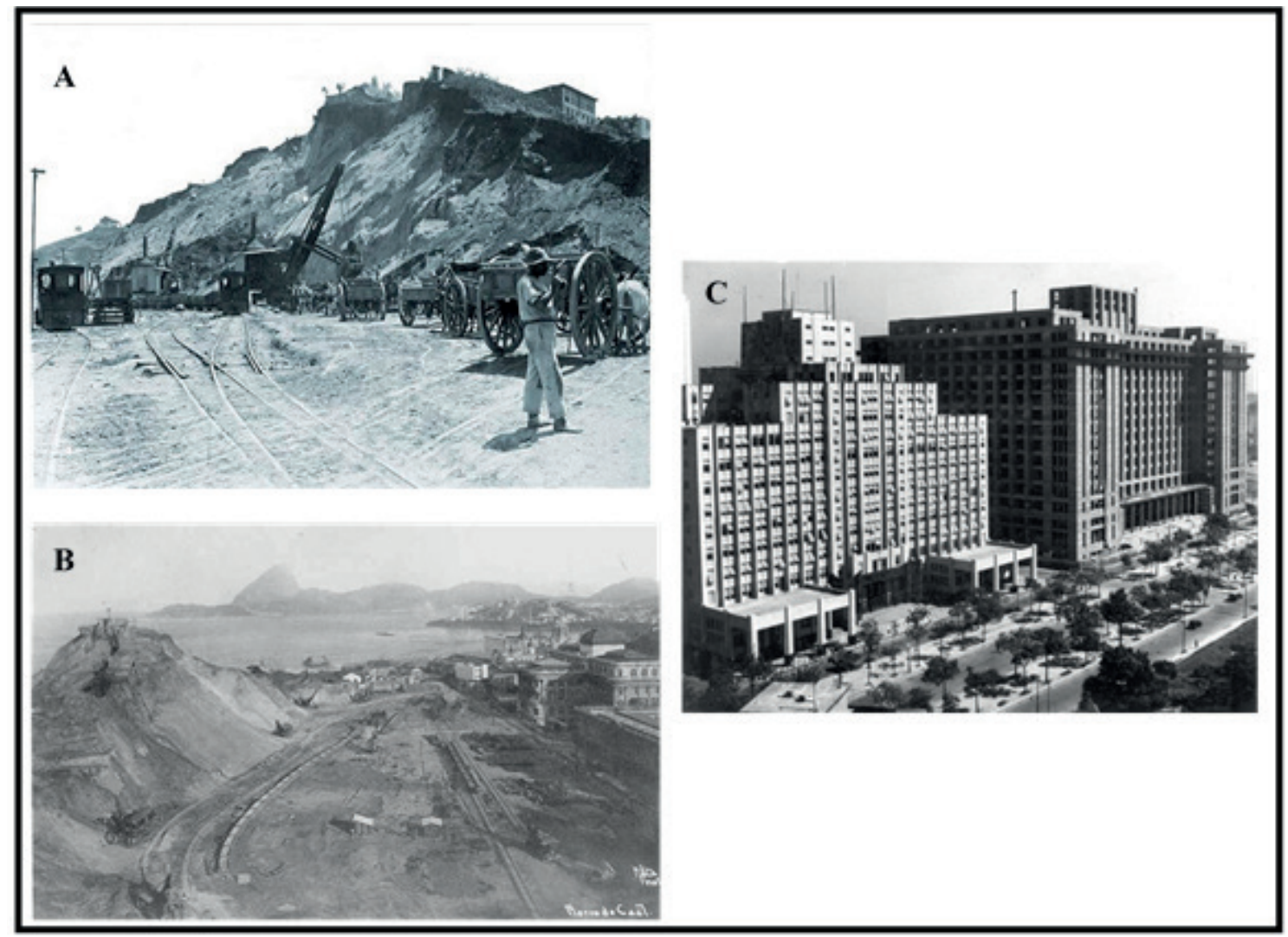

Fonte: Disponível em http://www.rioquepassou.com.br/2009/10/16/av-pres-antonio-carlos-e-ministerios-circa-1944/).

$\mathrm{Na}$ área do entorno da Lagoa Rodrigo de Freitas, também havia uma ocupação desordenada em forma de casebres (Figura 10), em uma área que se encontrava ainda muito pantanosa e insalubre. À época, os olhos das classes mais favorecidas se voltavam para a Zona Sul da cidade e, como os outros bairros já estavam basicamente ocupados, sobrou, como áreas livres, esse local onde a insalubridade era gerada pela existência do pântano. Assim, com o aterro da Lagoa, houve a retirada da população menos favorecida e o loteamento para a construção de moradias de elevado padrão. 
Figura 10. Fotografia da ocupação da Lagoa Rodrigo de Freitas na década de 1940 e o aspecto pantanoso e insalubre do local.

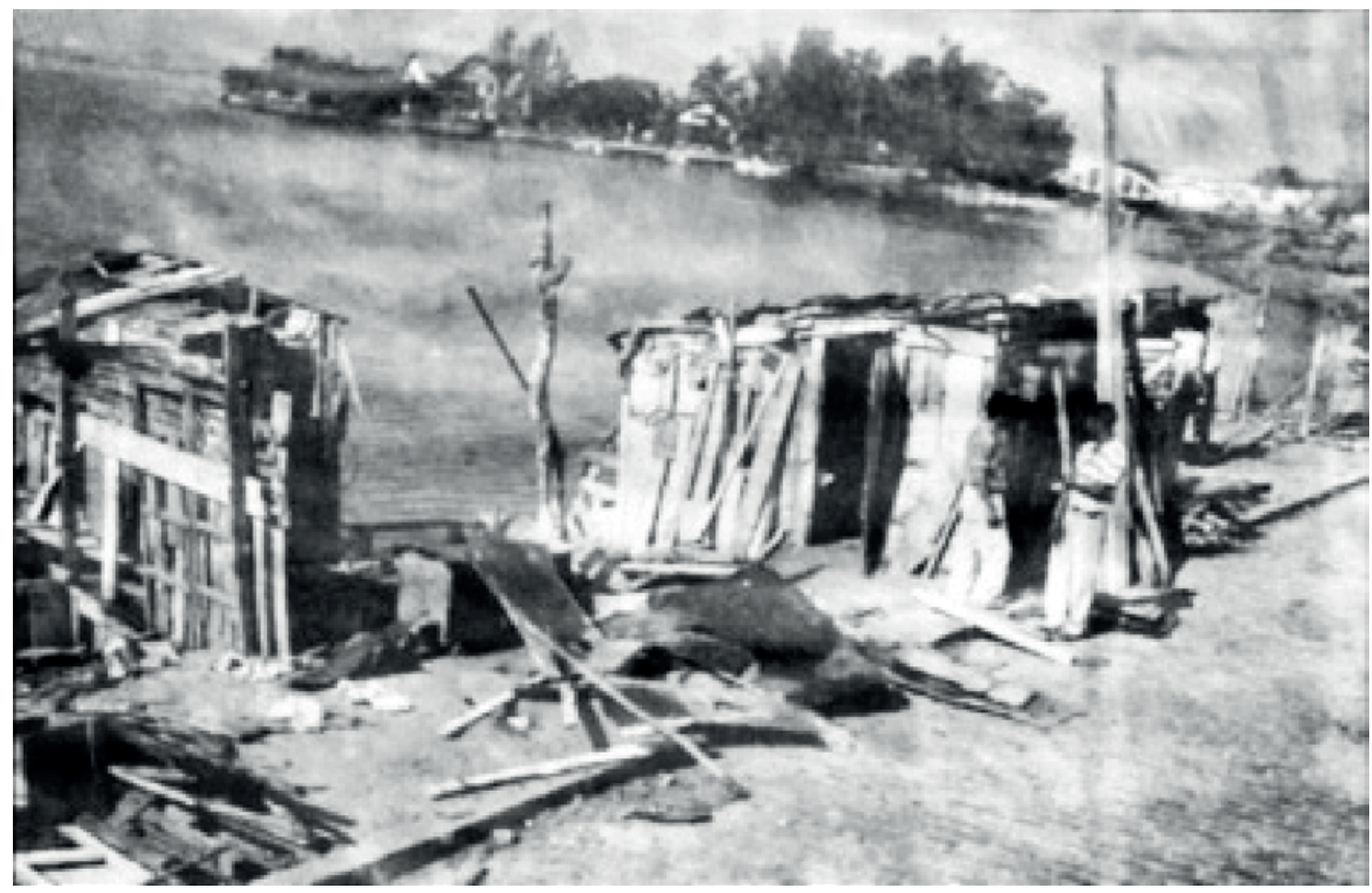

Fonte: Disponível em http://spiritosanto.wordpress.com/ page/9/?archives-list=1.

A Lagoa Rodrigo de Freitas estava localizada em uma área vista como importante para a cidade e, nesse caso, diferentemente da área do morro do Castelo, a importância da paisagem estava associada à moradia, enquanto a área do morro do Castelo tinha importância mais ligada à centralidade, aos negócios, ou seja, à economia nacional. Assim, a paisagem da Zona Sul como um todo passou a ter significado diferenciado, ligado à proximidade do oceano, que passou a ser visto como um "renovador para a alma” (Abreu, 2006). Dessa forma, as intervençōes antrópicas que modificaram essas paisagens urbanas, com a atribuição de novos significados culturais, ocorreram sob duas lógicas parecidas, porém distintas, no morro. A lógica no morro consistia em adaptar a paisagem às novas funçóes exigidas pela cidade, enquanto, na Lagoa, era a criação de uma paisagem com significado positivo, construindo, assim, uma nova área urbana valorizada.

Outros aterros foram realizados na Região Metropolitana do Rio de Janeiro e modificaram, de forma significativa, a paisagem natural da cidade, como foi o caso do Aterro do Flamengo e dos atuais bairros da Gamboa e da Saúde. O aterro junto aos bairros da Gamboa e da Saúde revelou-se de grande importância para a construção do cais do porto do Rio de Janeiro. E, embora a cidade, durante séculos, tenha tido boa parte de sua morfologia alterada pelos processos de ocupação e desenvolvimento, 
ainda hoje o contraste morfológico, as praias, alguns manguezais e ilhas, que ainda resistem a todo esse processo de degradação, são atrativos naturais que continuam a encantar brasileiros e estrangeiros.

\section{Fragilidade ambiental contemporânea no estado do Rio de Janeiro}

Falar de intervenções mais modernas que ocorreram no território fluminense, como, por exemplo, a rodovia Mário Covas (BR-101), e de todo padrão de intervenção que altera, principalmente, as condições hidrológicas sub e superficiais, é fundamental para se compreenderem a organização espacial e as questôes ambientais contemporâneas. E, para nos aprofundarmos na discussão dessas intervenções, é necessário trazer para o debate o conceito de fragilidade ambiental.

Para nós, esse conceito diz respeito à suscetibilidade que o ambiente apresenta a qualquer tipo de intervenção que gere alguma forma de dano, que, por suas características de sensibilidade aos impactos socioambientais adversos, possui baixa resiliência e pequena capacidade de recuperação. Como exemplo, temos as intervençóes em áreas ambientalmente frágeis, como lagos, lagunas, encostas de forte declive, restingas e manguezais (Diccionario de la Naturaleza, 1987). Essas intervenções devem ser muito bem avaliadas quando se pretende aplicá-las em políticas públicas de planejamento e/ou manejo territorial.

O estado do Rio de Janeiro apresenta características físicas de extrema fragilidade, quer sejam as relacionadas a seu sítio (ora terrenos de fortes declives, como as faixas serranas, ora terrenos de baixíssima declividade, como todas as áreas de baixadas quaternárias), quer estejam associadas a questōes de dinâmica atmosférica, pois se encontra posicionado em setores de influência de fatores climáticos extremamentes dinâmicos. Toma-se como exemplo a forte influência das frentes frias provenientes do Polo Sul e/ou a influência da faixa de nebulosidade orientada no sentido noroeste-sudeste, que se estende do sul da Amazônia ao Atlântico Sul-Central e caracteriza a Zona de Convergência do Atlântico Sul (ZCAS), influências que estão diretamente relacionadas aos inúmeros eventos de enchentes e/ou de movimentos gravitacionais de massa em diversos setores espaciais do estado.

Trazemos, aqui, alguns exemplos de mecanismos de uso dos solos, que, somados às características ambientais peculiares do estado, acabam gerando graves problemas à população.

Temos o exemplo do município de Angra dos Reis, situado em área litorânea no sul do estado, com uma beleza cênica reconhecida tanto nacional como internacionalmente. Esse município, contudo, passou por um processo de ocupação em um sítio com poucas áreas de baixo declive, avançando rumo às escarpas da serra da Bocaina (Figura 11). Observa-se que a inexistência de políticas adequadas à expansão urbana deixou a ocupação fora de controle, fazendo com que avançasse para áreas impróprias, pressionando e/ou degradando, dessa forma, a reserva de Mata Atlântica, característica dessa área. Esse processo ocupacional, ocorrido entre os anos 1970 e os anos 2000, foi provocado por diversos fatores, como a presença de estaleiros, da Petrobras, da usina nuclear, além da atração turística local, que corresponde a oportunidades de trabalho e, portanto, levou a uma significativa ocupação populacional, inclusive em áreas de difícil acesso e que apresentavam sérias questôes de fragilidade ambiental. Como resultado disso, é comum encontrar, no local, canais fluviais que sofrem com o 
assoreamento de seus leitos, derivado de processos erosivos nas altas encostas desmatadas, o que, somado a períodos de estiagem pluviométrica, conduz a problemas de abastecimento de água, além de degradação causada pela atividade de mineração ilegal (Figura 12).

Figura 11. Fotografia panorâmica do centro urbano do município de Angra dos Reis, localizado no sul fluminense.

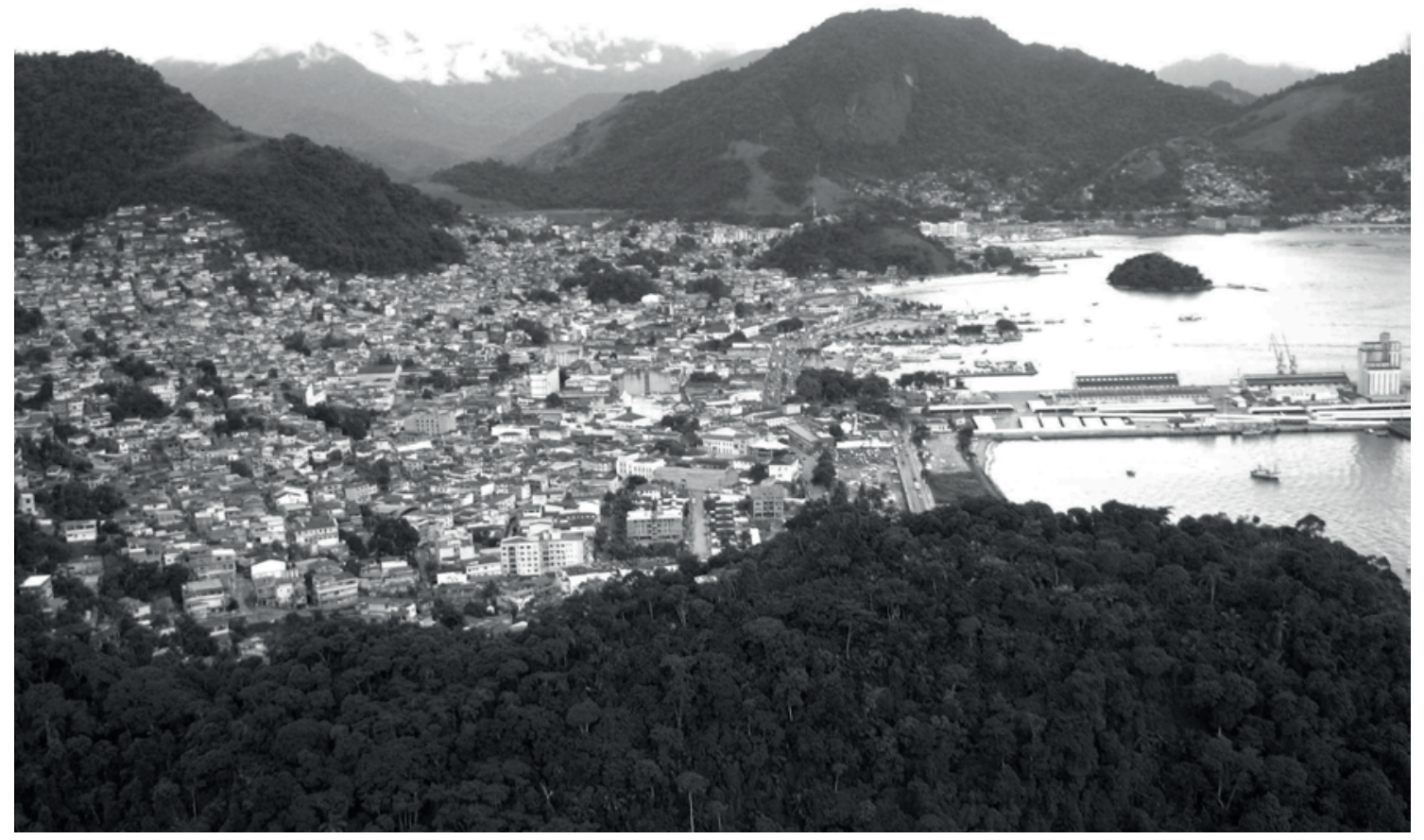

Foto: S. L. S. Silva (dezembro de 2010). 


\section{0 relevo do estado do Rio de Janeiro: cenário de beleza e fragilidade ambiental}

Figura 12. Fotografia do baixo curso do rio Japuíba, que ilustra aporte acentuado de carga sedimentar, com a redução significativa de seu leito fluvial. Observa-se ainda a atividade de extração ilegal de areia do leito fluvial pela presença de um caminhão coletor desse recurso mineral na parte inferior da foto.

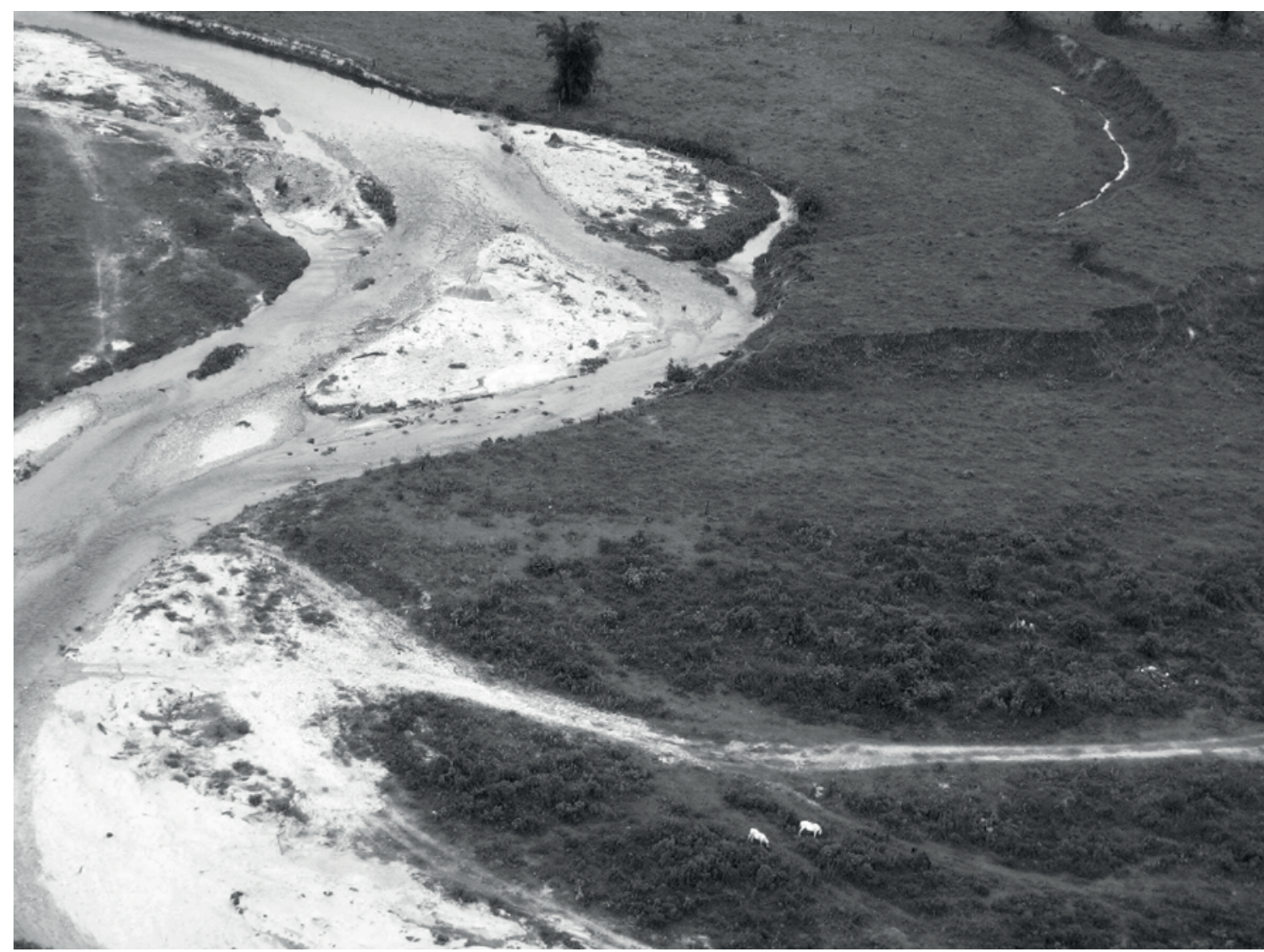

Foto: S. L. S. Silva (dezembro de 2010).

Ainda nesse município, encontramos ações indevidas do uso contemporâneo dos recursos naturais, como, por exemplo, cicatrizes representativas do uso indiscriminado de áreas de extração de material para construção civil, as quais são abandonadas sem nenhuma proposta de recuperação ambiental, como podemos observar na Figura 13A, que apresenta cicatrizes da área de extração mineral e uma voçoroca de grande extensão em sua base, bem próxima à rodovia Rio-Santos. Existe ainda outro exemplo de incoerência de uso, correspondente à construção de um lixão em área de colinas e morros com Mata Atlântica, ao lado de um canal fluvial (Figura 13B). 
Figura 13. A. Área de extração de saibro (produto de alteração de rochas quartzo-feldspáticas, como granitos e gnaisses) em feiçāo colinosa nos arredores da rodovia Rio-Santos (município de Angra dos Reis, RJ); B. Corte em feição de morro para a construção de um lixão a céu aberto pela prefeitura de Angra dos Reis na bacia do rio Ariró.
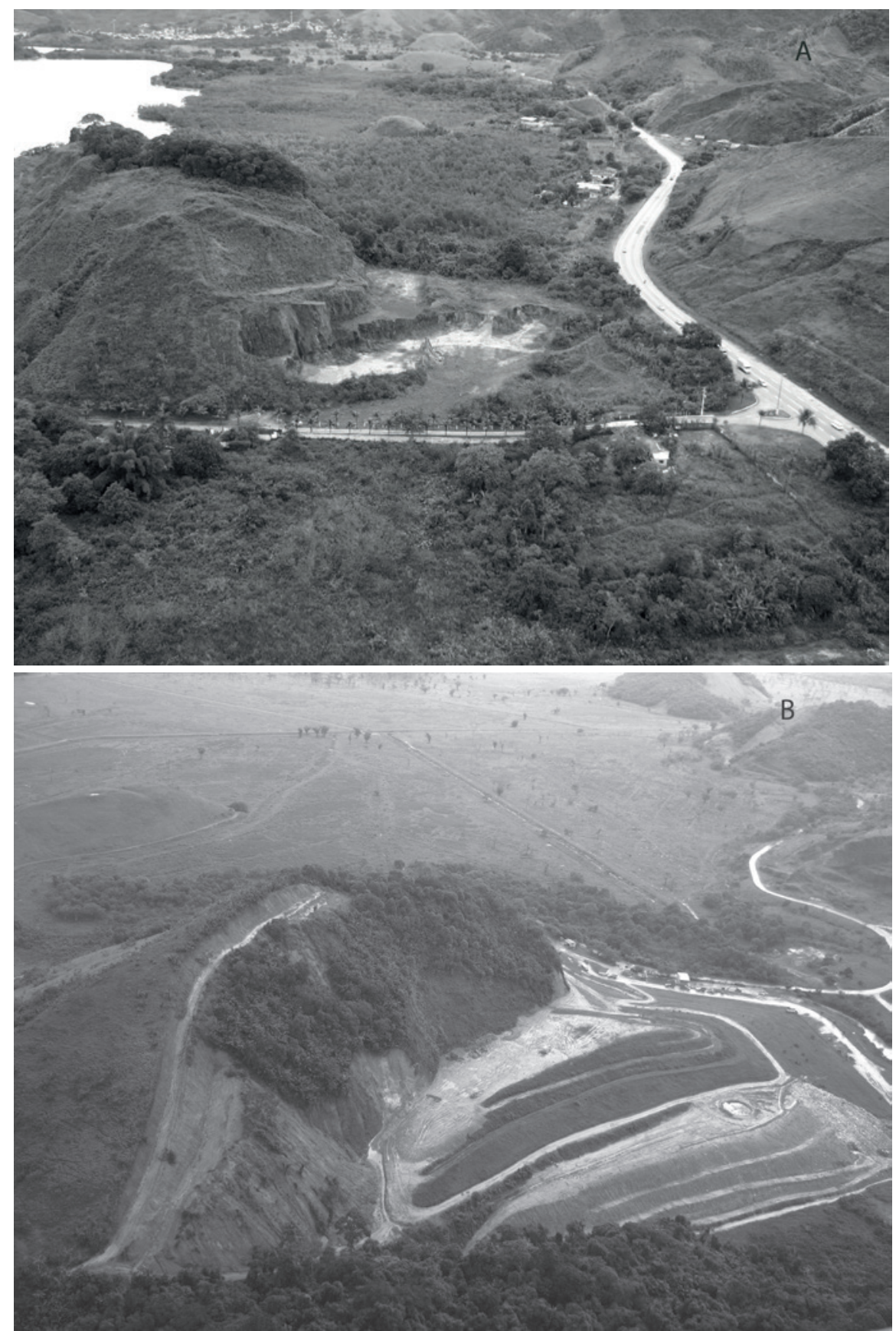

Foto: S. L. S. Silva (dezembro de 2010). 


\section{0 relevo do estado do Rio de Janeiro: cenário de beleza e fragilidade ambiental}

Além desses exemplos, é comum, em episódios de alta pluviosidade no município, assim como em tantos outros do estado, haver graves problemas com o desencadeamento de deslizamentos de encostas e enchentes. Angra dos Reis tem um triste histórico de inúmeros deslizamentos e quedas de blocos que causaram mortes e deixaram muitas pessoas desabrigadas, afetando diretamente a população e a economia local, como, por exemplo, nos eventos de 2002 (129,3 mm) e da virada do ano de 2009 para 2010 (142,9 mm). No entanto, sempre houve - e sempre haverá - eventos dessa magnitude em Angra e nas áreas serranas do estado. E os terrenos, que são naturalmente suscetíveis, por serem extremamente rasos, em razão do forte declive, somado aos elevados índices pluviométricos, são fatores primordiais na geração de tais processos geomorfológicos. No entanto, políticas adequadas e de controle e manejo do uso do solo poderiam amenizar tais catástrofes.

Em janeiro de 2011, a população da Região Serrana do Rio, constituída pelos municípios de Itaipava, Petrópolis, Teresópolis e Nova Friburgo, teve um dos maiores desastres ambientais já vivenciados, com uma série de eventos de deslizamentos, corridas de detritos e enchentes. Tudo isso arrasou, quase por completo, alguns vilarejos, como podemos observar na Figura 14, em que a imagem nos revela a força do agente de transporte, que foi capaz de movimentar blocos rochosos de diversos tamanhos, destruindo o que encontrava pela frente por onde passava, ao longo do eixo do córrego da Posse, em Petrópolis. Esses eventos, contudo, são recorrentes, pois ainda é possível observar in situ, nos barrancos que foram escavados ao longo do antigo leito fluvial, depósitos de blocos de diversos diâmetros acamados em uma matriz areno-argilosa, demonstrando que, nessa área, assim como em quase todas as áreas serranas do estado, esses processos representam mecanismos naturais de evolução da paisagem.

Os elevados índices pluviométricos, que ocorrem, principalmente, nos meses de verão, revelam-se o input de energia. No entanto, dirigentes de órgãos públicos devem estar atentos aos demais fatores ambientais, como, por exemplo, tipo de solo, conformação geomorfológica, direção preferencial dos fluxos d'água, entre outras características do terreno, no momento de colocar em prática as políticas de uso e manejo, buscando sempre evitar, ou pelo menos amenizar, as proporções das catástrofes já anunciadas em um sítio extremamente sensível às fragilidades ambientais. 
Figura 14. Imagem da corrida de detritos no vale do córrego da Posse, município de Petrópolis (RJ), em janeiro de 2011.

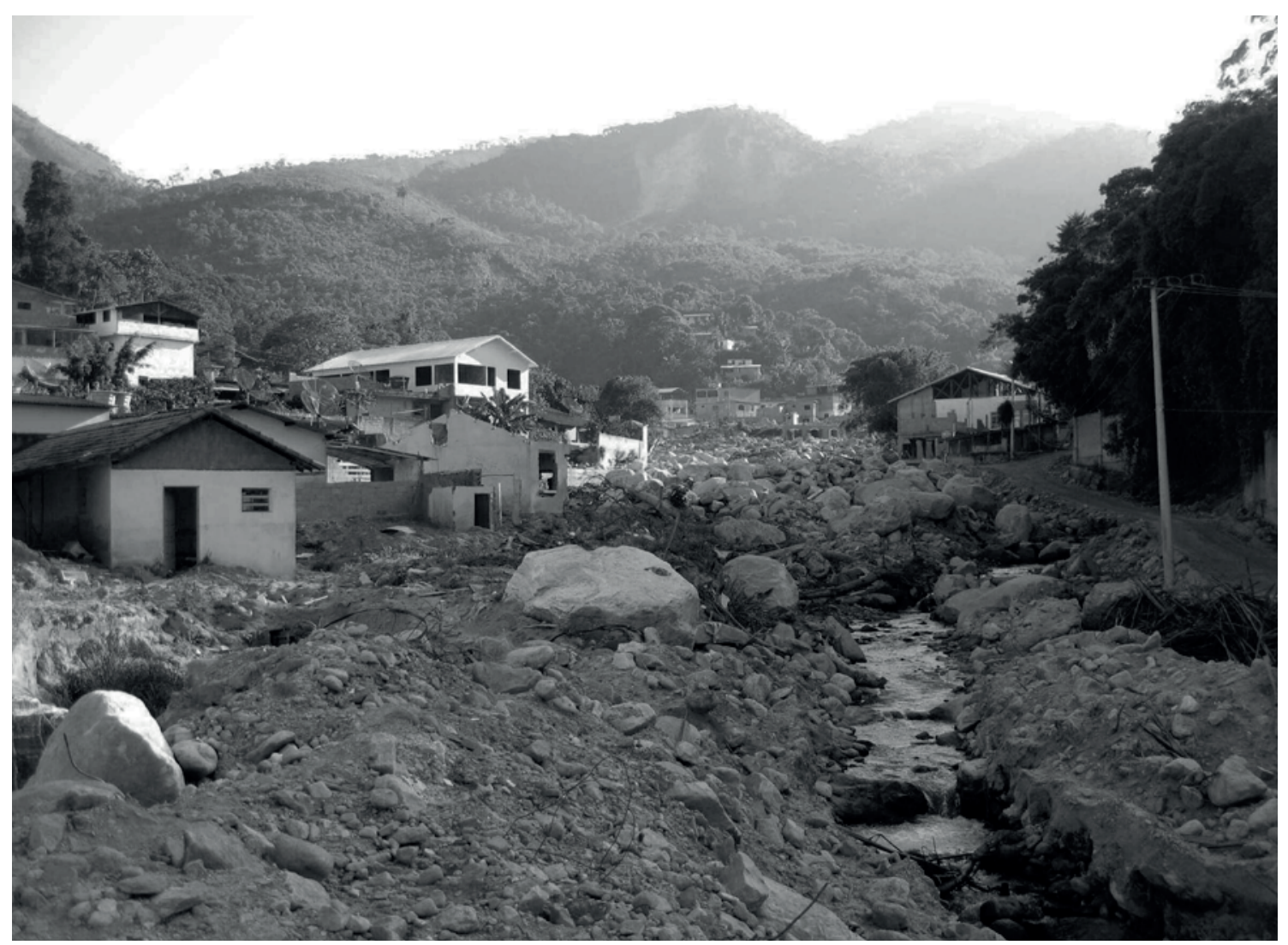

Foto: T. M. Silva (maio de 2011).

\section{Considerações finais}

Por representar uma das mais importantes referências naturais e culturais do Brasil, o estado do Rio de Janeiro sempre terá relevância no país, devendo-se sempre manter sua riqueza físico-ambiental e o bem-estar e a qualidade de vida de seus habitantes (Silva et al., 2015). Embora, na última década, tenha havido um prenúncio de recuperação econômica do estado, em função de sua base industrial expressiva, com a instalação de refinarias de petróleo, estaleiros, indústrias siderúrgicas, metalúrgicas, petroquímicas, entre outras, no último ano uma nova crise econômica se instalou, trazendo muita preocupação no que tange também aos mecanismos de degradação e poluição ambiental. Deve-se, contudo, buscar mecanismos capazes de manter a integridade de uma das áreas mais importantes do país, que desempenha papel fundamental na externalização de uma imagem positiva do Brasil no exterior.

Com a realização da Copa do Mundo de 2014 no Brasil e das Olimpíadas de 2016 no estado, os olhos do mundo se voltaram para nosso país e, dessa forma, há grande interesse em seu desenvol- 
vimento e crescimento sustentável, com vistas a melhorar uma imagem degradada por longos quinhentos anos de mau uso e ausência de manejo adequado. Acredita-se, dessa forma, que, se houver políticas públicas adequadas às condições físico-naturais peculiares dos terrenos fluminenses e, em consequência, dos processos erosivo-deposicionais advindos da relação entre tais características e a entrada de energia no sistema ambiental - que, em geral, está atrelada aos elevados índices pluviométricos -, será possível retomar um crescimento econômico que respeite o belo cenário natural do estado do Rio de Janeiro.

\section{Referências}

ABREU, Maurício Abreu. Evolução urbana do Rio de Janeiro. 4 ed. Rio de Janeiro: Instituto Pereira Passos - IPP/Prefeitura da Cidade do Rio de Janeiro, 2006 [1987]. 156p.

AMADOR, Elmo da Silva. "Baía de Guanabara: um balanço histórico". In ABREU, M. A. et al. (orgs.). Natureza e sociedade do Rio de Janeiro. Rio de Janeiro: Secretaria Municipal de Cultura, Turismo e Esportes, Departamento Geral de Documentação e Informação Cultural, Divisão de Editoração, 1992, pp. 201-58.

- Baía de Guanabara e ecossistemas periféricos: características geoambientais, formaçāo e ecossistemas. Rio de Janeiro: Interciência, 2012. 432p.

ASMUS, Haroldo Erwin e FERRARI, André Luiz. "Hipótese sobre a causa do tectonismo cenozóico na região sudeste do Brasil”. In PROJETO REMAC. Aspectos estruturais da margem continental leste e sudeste do Brasil. Rio de Janeiro: Petrobras/Cenpes/Dintep, 1978, v. 4, pp. 75-88.

DICCIONARIO de la Naturaleza, Hombre, Ecologia, Paisaje. Madri: Espasa-Calpe, 1987. 1.016p. Disponível em http://www.ecolnews.com.br/dicionarioambiental/ referencias_bibliograficas.htm. Acesso em 23 jan. 2016.

FERNANDES, Nelson Ferreira et al. "Rio de Janeiro: a metropolis between granite-gneiss massifs". In MIGÓN, P. (org.). Geomorphological landscapes of the world. Berlim, primavera de 2010, pp. 89-100.

FERRARI, André Luiz. "Geologia”. In SERRA, M. V. e SERRA, M. T. F. Guia de história natural do Rio de Janeiro. Rio de Janeiro: Cidade Viva, 2012, pp. 52-75.

HEILBRON, Mônica et al. "Correlation of Neoproterozoic terranes between the Ribeira Belt, SE Brazil and its African counterpart: comparative tectonic evolution and open questions", Geological Society Special Publication, 2008, v. 294, pp. 211-37.

MACEDO, J. M. et al. "O tectonismo meso-cenozoico da região Sudeste”. In Simpósio de Geologia do Sudeste. Atas... São Paulo: SBG/SP-RJ, 1991, pp. 429-33.

PINHEIRO, Eliane Canedo de Freitas. Baía de Guanabara: uma biografia de uma paisagem. Rio de Janeiro: Andrea Jakobsson Estúdio, 2005. 271p.

PROUS, André. Arqueologia brasileira. Brasília: Universidade de Brasília, 1992. 606p.

RICCOMINI, C. O Rift Continental do Sudeste do Brasil (tese). USP, 1989. 
- Tectonismo gerador e deformador dos depósitos sedimentares pós-gondvânicos da porção centrooriental do Estado de São Paulo e áreas vizinhas (tese de livre-docência). USP, 1995. 100p.

SCHMITT, Renata da Silva et al. "O projeto caminhos geológicos: divulgação científica dos monumentos geológicos do estado do Rio de Janeiro”. In Congresso Brasileiro de Extensão Universitária, 2, Belo Horizonte. Anais... Belo Horizonte, 2004. 8p.

SERRA, M. V. e SERRA, M. T. "Região Metropolitana do Rio de Janeiro: expansão urbana e meio ambiental”. In —. Guia de história natural do Rio de Janeiro. Rio de Janeiro: Cidade Viva, 2012, pp. 12-4.

SILVA, Telma Mendes da. A estruturação geomorfológica do Planalto Atlântico no estado do Rio de Janeiro (tese). UFRJ, 2002.

—. "Geomorfologia do estado do Rio de Janeiro: distribuição espacial das feições morfológicas e contexto evolutivo". In BICALHO, A. M. S. e GOMES, P. C. C. (orgs.). Questóes metodológicas e novas temáticas na pesquisa geográfica. Rio de Janeiro: Publit, 2009, pp. 227-48.

— et al. "The Guanabara Bay, a Giant Body of Water Surrounded by Mountains in the Rio de Janeiro Metropolitan Area”. In VIEIRA, B. C. et al. (orgs.). Landscapes and Landsforms of BrazilWorld Geomorphological Landscapes. Nova Iorque/Londres, primavera de 2015, pp. 389-99.

TUPINAMBÁ, Miguel et al. "Evolução tectônica e magmática da faixa ribeira entre o Neoproterozoico e o Paleozoico Inferior na Região Serrana do estado do Rio de Janeiro, Brasil”, Anuário do Instituto de Geociências, UFRJ, 2012, vv. 35-2, pp. 140-51. 